\title{
Cognitive stimulation in people with mental disorders in the community: an integrative review
}

\author{
Estimulação cognitiva em pessoas com doença mental na comunidade: revisão integrativa
}

Estimulación cognitiva en personas con enfermedades mentales en la comunidad: revisión integrativa

\section{Vanessa Alexandra Henriques Silva' ORCID: 0000-0003-2382-1699 \\ Paulo Rosário Carvalho Seabra' ORCID: 0000-0001-8296-1021}

'Universidade Católica Portuguesa. Lisboa, Portugal.

How to cite this article: Silva VAH, Seabra PRC. Cognitive stimulation in people with mental disorders in the community: an integrative review. Rev Bras Enferm. 2020;73(1):e20180192. doi: http://dx.doi.org/10.1590/0034-7167-2018-0192

\section{Corresponding Author:} Vanessa Silva

E-mail:vanessahqsilva@hotmail.com

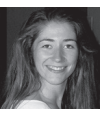

EDITOR IN CHIEF: Antonio José de Almeida Filho

Submission: 04-18-2018

Approval: 06-01-2018

\section{ABSTRACT}

Objective: to analyze Cognitive Stimulation techniques effectiveness in the community and at home, in people with stabilized mental illness and their families. Method: an Integrative Literature Review, with inclusion criteria for primary studies that assess the Cognitive Stimulation techniques effectiveness in people with stable mental illness, older than 18 years, in the community and at home. Six articles were selected. Results: improvement of cognitive abilities such as attention, work memory and executive functions was observed. No conceptual differences or results were found among Cognitive Stimulation programs for people with different pathologies; computer tools are increasingly being used; sample size is limiting gain analysis; the nurse's role has not been clarified; family gains were not studied. Final considerations: the results obtained in this review reveal the need to know more about the theme.

Descriptors: Cognitive Remediation; Rehabilitation; Mental Disorders; Psychiatric Nursing; Evaluation of the Efficacy-Effectiveness of Interventions.

\section{RESUMO}

Objetivo: analisar a efetividade das técnicas de Estimulação Cognitiva em contexto comunitário e domiciliário, na pessoa com doença mental estabilizada e suas famílias. Método: Revisão Integrativa da Literatura, tendo como critérios de inclusão estudos primários que avaliem a efetividade das técnicas de Estimulação Cognitiva em pessoas com doença mental em fase estável, com idade superior a 18 anos, na comunidade e domicílio. Foram selecionados seis artigos. Resultados: verificou-se melhoria de capacidades cognitivas como atenção, memória de trabalho e funções executivas; não se apuraram diferenças conceptuais, nem nos resultados, entre os programas de Estimulação Cognitiva para pessoas com diferentes patologias; as ferramentas informáticas são cada vez mais utilizadas; o tamanho das amostras é limitador da análise dos ganhos; o papel do enfermeiro não foi esclarecido; os ganhos para as famílias não foram estudados. Considerações finais: os resultados obtidos nesta revisão revelam a necessidade de se conhecer mais sobre a temática.

Descritores: Remediação Cognitiva; Reabilitação; Transtornos Mentais; Enfermagem Psiquiátrica; Avaliação de Eficácia-Efetividade de Intervenções.

\section{RESUMEN}

Objetivo: analizar la efectividad de las técnicas de Estimulación Cognitiva en el contexto de la comunidad y el hogar en la persona con enfermedad mental estabilizada y sus familias. Método: Revisión Integrativa de la Literatura, con los criterios de inclusión como estudios primarios que evalúan la efectividad de las técnicas de Estimulación Cognitiva en personas con enfermedad mental estable, mayores de 18 años, en la comunidad y en el hogar. Se seleccionaron seis artículos. Resultados: se observó una mejora de las capacidades cognitivas como la atención, la memoria de trabajo y las funciones ejecutivas; no se encontraron diferencias conceptuales ni resultados entre los programas de Estimulación Cognitiva para personas con diferentes patologías; las herramientas informáticas son cada vez más utilizadas el tamaño de las muestras está limitando el análisis de las ganancias; el papel de la enfermera no ha sido aclarado; Las ganancias para las familias no fueron estudiadas. Consideraciones finales: los resultados obtenidos en esta revisión revelan la necesidad de saber más sobre el tema.

Descriptores: Remediación Cognitiva; Rehabilitación; Trastornos Mentales; Enfermería Psiquiátrica; Evaluación de Eficacia-Efectividad de Intervenciones. 


\section{INTRODUCTION}

There are several studies arguing that pharmacological treatment is enhanced when followed_up by a non-pharmacological treatment that seeks to reduce mental illness effects on functional capacity, social relations and quality of life of people with mental illness ${ }^{(1)}$. Mental illness often causes cognitive deficits, and these changes can be observed in people with Schizophrenia( ${ }^{(2)}$ Bipolar Affective Disorder ${ }^{(3)}$ and Major Depressive Disorder ${ }^{(4)}$. Cognitive deficits are cognitive abilities deterioration such as memory, attention and/or executive functions, among others ${ }^{(5-6)}$, leading to a decrease in the person's ability to remain autonomous in their daily lives.

Stimulation and compensation of these cognitive deficits reveals as one of the areas of expertise of nurses specialized in Mental and Psychiatric Health Nursing (MPHN), taking into account their role in promoting misaligned responses of the person who is going through transition, while at the same time seeking to prevent mental illness worsening, to promote recovery and increase in quality of life $\mathrm{f}^{(7)}$.

Raising Cognitive Stimulation (CS) as a way to promote stimulation, compensation and promotion of neurocognitive abilities ${ }^{(8)}$, in recent years, studies have sought to quantify precisely the results obtained by this non-pharmacological intervention. CS techniques must be understood as a set of strategies and exercises that seek to promote certain cognition areas, and can be implemented in a group or individually, usually performed in a certain period of time. They seek certain objectives and have as goal people (and their families) living with cognitive changes empowerment, providing them information and strategies, so that they are able to improve their daily lives ${ }^{(9)}$. These techniques can take on different designations and typologies (Cognitive Remediation and Cognitive Rehabilitation) ${ }^{(10)}$.

Efficacy, efficiency and/or effectiveness assessment of therapies encompassing CS techniques occurs with the purpose of understanding how one can, in a more effective way, enable a person with mental illness and his family to adapt and live with existing cognitive deficits, in the most autonomous and organized way possible ${ }^{(9)}$. In view of CS techniques comprehensiveness, there is questioning about the state of the art in relation to effective results of these techniques with the person with stable mental illness in a community and at home, and benefits for their families. The need for an integrative review emerged as a way to synthesize the evidence in this context and with these specific diseases, since there were studies of people with institutionalized neurodegenerative disease.

\section{OBJECTIVE}

To analyze CS techniques effectiveness in the community and at home, in people with stabilized mental illness and their families.

\section{METHOD}

While research is directed to experimental studies discussion, this integrative review is based on the research question: what is CS techniques effectiveness performed by nurses in people with stable mental illness and their families/caregivers in a community context?

In order to answer this question, it is necessary to achieve the following objectives: (1) To identify the results obtained with interventions and CS techniques in people with stable/chronic mental illness; (2) To see if there are differences in intervention effectiveness in people with different mental illnesses (schizophrenia, bipolar disorder and major depressive disorder); (3) To identify the role of nurses in the performance of these techniques and the relevance of their performance; (4) To understand the results of these techniques in family/caregivers.

After validation at DeCS (Descritores em Ciências da Saúde Health Sciences Descriptors), search terms (descriptors and the like) were defined for the data platforms consulted: (a) cognitive stimulation, or cognitive rehabilitation, or cognitive remediation, or cognitive training (identifiable in the title), (b) schizophr *, or bipolar, or depressi *, or mental illness, or mental disorder (identifiable in title), (c) person, or people, or family, or caregive* (identifiable in the title) and (d) effectiveness, or efficacy, or efficiency, or effective, or results, or outcomes (identifiable in the title).

(1) Primary studies assessing the efficacy, efficiency, and/or effectiveness of CS interventions, techniques, and/or programs in individuals and/or their families; (2) Studies whose samples included people with stable/chronic stage mental illness, namely schizophrenia, bipolar disorder, depression and similar illnesses/ of the same group, living and receiving care in the community (in units of prolonged evolution or to receive care in regime of outpatient clinic) or at home, aged 18 years or more; (3) Studies with nurses as intervenient; (4) Articles in Portuguese, English or Spanish; and (5) Articles published between 2001 and 2017, with full text available and free access were the inclusion criteria.

(1) Studies whose samples included people with acute mental illness; hospitalized in psychiatric hospital services; under the age of 18; (2) Studies whose samples involved people with some form of dementia (Alzheimer's or Parkinson's disease) or with neurological changes (neurodegenerative, traumatic and developmental changes), including depression consequent to Stroke; (3) Studies analyzing cognitive therapies effects on vocational rehabilitation and job search/acquisition; (4) Studies whose samples included people addicted to substances (such as alcohol or other substances) or with changes in eating behavior (anorexia or bulimia); (5) Studies assessing the cognitive-behavioral therapy effectiveness; and (6) Systematic and integrative literature reviews were the exclusion criteria.

The research was carried out on EBSCO and Google Scholar platforms between September $16^{\text {th }}$ and $18^{\text {th }} 2017$. With search term placement in databases and definition of temporal and language constraints/limitations, 32 articles were identified.

Following figure 1, which shows eligibility of articles, of the 32 articles identified, 7 were repeated and 4 were excluded after reading the title, since they did not answer the research question of this ILR. After reading the abstract and comparing the inclusion and exclusion criteria, 11 were excluded because they were articles dealing with vocational rehabilitation and employment $(n=4)$ they did not have the full text available $(n=4)$, they were a systematic literature review $(n=1)$, they addressed only disease cognitive factors $(n=1)$ and for addressing depression following a 


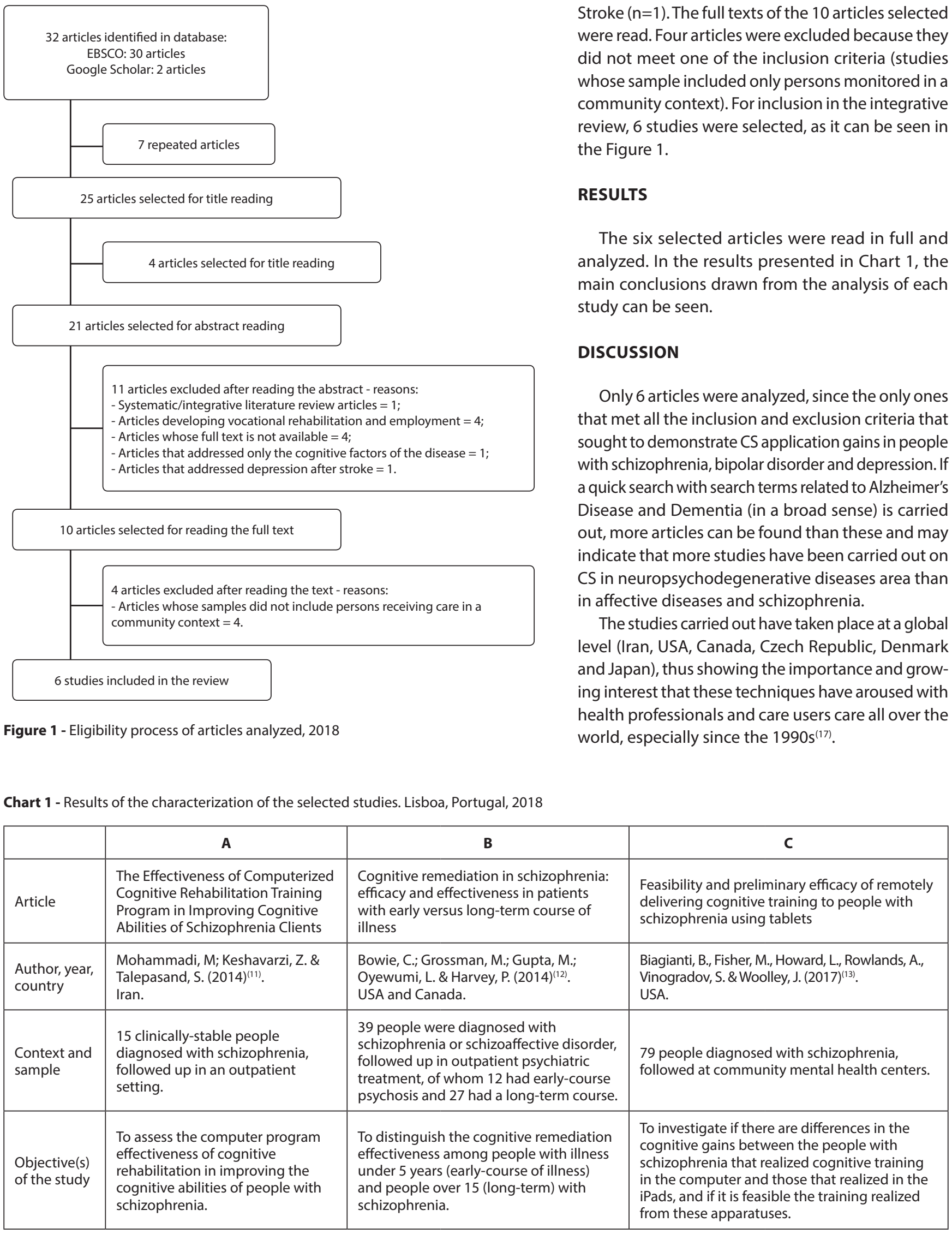

To be continued 


\begin{tabular}{|c|c|c|c|c|c|}
\hline & A & & B & & C \\
\hline $\begin{array}{l}\text { Moments } \\
\text { and } \\
\text { assessment } \\
\text { tools (scales) }\end{array}$ & $\begin{array}{l}\text { Assessment took place in four } \\
\text { moments: before the program, } \\
\text { immediately after, one month and } \\
\text { three months later (follow-up). } \\
\text { "Symptom assessment: Positive and } \\
\text { Negative Syndrome Scale (PANSS); } \\
\text { „Neuropsychological assessment: } \\
\text { Continuous Performance Test } \\
\text { Identical Pair Version (CPTIP); } \\
\text { „Cognitive function: Revised } \\
\text { Wechsler Adult Intelligence } \\
\text { Scale (WAIS) and Prospective } \\
\text { and Retrospective Memory } \\
\text { Questionnaire (PRMQ). }\end{array}$ & \multicolumn{2}{|c|}{$\begin{array}{l}\text { Assessment performance in two } \\
\text { moments: before the program and one } \\
\text { (1) week after its end. } \\
\text { „Cognition: Brief Assessment of } \\
\text { Cognition in Schizophrenia; } \\
\text { „Clinical Symptoms: Positive and } \\
\text { Negative Syndrome Scale (PANSS); } \\
\text { „Skills assessment: Social Skills } \\
\text { Performance Assessment, roleplays and } \\
\text { Specific Levels of Functioning (SLOF). }\end{array}$} & \multicolumn{2}{|c|}{$\begin{array}{l}\text { Assessment performance in two moments: } \\
\text { before the program and after its end. } \\
\text { „Diagnostic assessment: initial interview; } \\
\text { „Cognition: MATRICS Consensus Cognitive } \\
\text { Battery (MCCB), Hopkins Verbal Learning Test-R } \\
\text { (HVLT-R) and Brief Visuospatial Memory Test-R } \\
\text { (BVMT-R); } \\
\text { „Symptomatology and Functional Results: } \\
\text { Positive and Negative Syndrome Scale (PANSS), } \\
\text { Quality of Life Scale (QLS), Social Functioning } \\
\text { Scale (SFS) and UCSD Performance Based Skill } \\
\text { Assessment (UPSA). }\end{array}$} \\
\hline $\begin{array}{l}\text { Intervention } \\
\text { (CS } \\
\text { technique } \\
\text { used and } \\
\text { training } \\
\text { frequency) }\end{array}$ & $\begin{array}{l}\text { Therapy consists of } 20 \text { individual } \\
\text { sessions, two per week (for about } \\
18 \text { weeks), with } 60 \text { minute- } \\
\text { duration. } \\
\text { The intervention came from the } \\
\text { Rehacome software, which trains } \\
\text { attention, concentration, working } \\
\text { memory and executive functions. }\end{array}$ & \multicolumn{2}{|c|}{$\begin{array}{l}\text { Program that uses exercises in } \\
\text { computers. } \\
\qquad \text { It describes that the detailed } \\
\text { program is described in an article by } \\
\text { Bowie, McGurk, Mausbach, Patterson and } \\
\text { Harvey (2012). }\end{array}$} & \multicolumn{2}{|c|}{$\begin{array}{l}\text { 40-hour exercise program in BrainHQ software, } \\
21 \text { people on a fixed computer (supervised) } \\
\text { and } 26 \text { people on an iPad (unsupervised). Each } \\
\text { person was asked to train } 60 \text { minutes a day, } 5 \\
\text { days a week. }\end{array}$} \\
\hline $\begin{array}{l}\text { Nurse as } \\
\text { intervener }\end{array}$ & $\begin{array}{l}\text { No. } \\
\text { The program was conducted by a } \\
\text { psychologist. }\end{array}$ & \multicolumn{2}{|c|}{$\begin{array}{l}\text { No. } \\
\text { Psychologists conduct the program. }\end{array}$} & \multicolumn{2}{|c|}{$\begin{array}{l}\text { It does not define professionals, but refers that } \\
\text { there was little intervention. }\end{array}$} \\
\hline $\begin{array}{l}\text { Caregiver as } \\
\text { intervener }\end{array}$ & No. & \multicolumn{2}{|l|}{ No. } & \multicolumn{2}{|l|}{ No. } \\
\hline Results & $\begin{array}{l}\text { The software improved attention, } \\
\text { working memory, and prospective } \\
\text { and retrospective memory. } \\
\text { Regarding reaction time, there } \\
\text { were no long-term improvements. } \\
\text { In the working memory, results } \\
\text { demonstrated that improvements } \\
\text { remain long-term. } \\
\text { The software did not produce any } \\
\text { improvement over the positive } \\
\text { and negative effects of the disease. }\end{array}$ & \multicolumn{2}{|c|}{$\begin{array}{l}\text { There are greater improvements in } \\
\text { cognitive abilities in people with early- } \\
\text { onset disease than with more years of } \\
\text { illness. } \\
\text { This difference was visible in } \\
\text { psychomotor speed, complex } \\
\text { information processing speed, working } \\
\text { memory and planning capacity areas. } \\
\text { If cognitive remediation is used in early } \\
\text { stages of the disease, it will have more } \\
\text { robust and relevant clinical, cognitive } \\
\text { and functional effects. } \\
\text { There were no improvements in verbal } \\
\text { memory, verbal fluency and social } \\
\text { competence. }\end{array}$} & \multicolumn{2}{|c|}{$\begin{array}{l}\text { Cognitive remediation through iPads is } \\
\text { feasible, since people who used these portable } \\
\text { devices had the same earnings as those who } \\
\text { completed the program on a computer. } \\
\text { Both groups showed significant cognitive } \\
\text { improvements in verbal learning, and problem- } \\
\text { solving skills and working memory, regardless } \\
\text { of the device they used. } \\
\text { People from the sample showed improvements } \\
\text { in quality of life and social functioning, and } \\
\text { they not have computers/iPads that influenced } \\
\text { the magnitude of this improvement. }\end{array}$} \\
\hline \multirow[t]{2}{*}{$\begin{array}{l}\text { Limitations } \\
\text { reported in } \\
\text { the article }\end{array}$} & $\begin{array}{l}\text { - There was no randomness in the } \\
\text { sample choice; } \\
\text { - The group consisted of only } 15 \\
\text { people; } \\
\text { - Further follow-up assessments } \\
\text { are needed to prove the effects of } \\
\text { training. }\end{array}$ & \multicolumn{2}{|c|}{$\begin{array}{l}\text { - Selected sample for convenience (from } \\
\text { a study already done); } \\
\text { - No follow-up assessment. }\end{array}$} & \multicolumn{2}{|c|}{$\begin{array}{l}\text { - Each person in the sample could choose the } \\
\text { device they preferred to use, and the iPads } \\
\text { group included younger people with less } \\
\text { symptomatology than the other. } \\
\text { - Small sample; } \\
\text { - No follow-up assessment. }\end{array}$} \\
\hline & $\mathrm{D}$ & & $E$ & & $\mathrm{~F}$ \\
\hline Article & $\begin{array}{l}\text { Personalized cognitive training in ur } \\
\text { bipolar disorder: a study of cognitiv }\end{array}$ & $\begin{array}{l}\text { polar and } \\
\text { functioning }\end{array}$ & $\begin{array}{l}\text { Effects of Short-Term Cogn } \\
\text { on Cognitive Dysfunction i } \\
\text { Remitted Individuals with } \\
\text { Results of a Randomised Cc }\end{array}$ & $\begin{array}{l}\text { Je Remediation } \\
\text { Partially or Fully } \\
\text { olar Disorder: } \\
\text { trolled Trial }\end{array}$ & $\begin{array}{l}\text { Efficacy of Cognitive } \\
\text { Rehabilitation Using } \\
\text { Computer Software } \\
\text { With Individuals Living } \\
\text { With Schizophrenia: A } \\
\text { Randomized Controlled } \\
\text { Trial in Japan }\end{array}$ \\
\hline $\begin{array}{l}\text { Author, year, } \\
\text { country }\end{array}$ & $\begin{array}{l}\text { Preiss, M., Shatil, E., Cermákova, R., C } \\
\text { D. \& Ram, I. }(2013)^{(14)} \text {. } \\
\text { Czech Republic. }\end{array}$ & nermanová, & $\begin{array}{l}\text { Demant, K., Vinberg, M., Ke } \\
\text { K. }(2015)^{(15)} \text {. } \\
\text { Denmark. }\end{array}$ & ng, L. \& Miskowiak, & $\begin{array}{l}\text { Iwata, K. et al. }(2017)^{(16)} \text {. } \\
\text { Japan. }\end{array}$ \\
\hline
\end{tabular}


Chart 1 (concluded)

\begin{tabular}{|c|c|c|c|}
\hline & A & B & C \\
\hline $\begin{array}{l}\text { Context and } \\
\text { sample }\end{array}$ & $\begin{array}{l}45 \text { people were diagnosed with unipolar } \\
\text { depression or in the depressive phase of bipolar } \\
\text { disorder, followed-up in a psychiatry outpatient } \\
\text { setting, and who had a computer at home }\end{array}$ & $\begin{array}{l}46 \text { people were diagnosed with bipolar } \\
\text { disorder, followed-up in psychiatric community } \\
\text { centers }\end{array}$ & $\begin{array}{l}60 \text { people were } \\
\text { diagnosed with } \\
\text { schizophrenia, followed- } \\
\text { up in a psychiatric } \\
\text { treatment outpatient, } \\
\text { where they already } \\
\text { performed psychiatric } \\
\text { rehabilitation activities }\end{array}$ \\
\hline $\begin{array}{l}\text { Objective(s) } \\
\text { of the study }\end{array}$ & $\begin{array}{l}\text { To examine the impact of cognitive training } \\
\text { on the functioning of people with unipolar or } \\
\text { bipolar depression and the level of attention and } \\
\text { executive control. }\end{array}$ & $\begin{array}{l}\text { To assess whether cognitive remediation } \\
\text { improves cognitive function and psychosocial } \\
\text { functioning compared to the control group of } \\
\text { people with bipolar disorder. }\end{array}$ & $\begin{array}{l}\text { To assess whether } \\
\text { cognitive remediation is } \\
\text { effective in promoting } \\
\text { cognitive functioning } \\
\text { and social functioning } \\
\text { in people with } \\
\text { schizophrenia. }\end{array}$ \\
\hline $\begin{array}{l}\text { Moments } \\
\text { and } \\
\text { assessment } \\
\text { tools (scales) }\end{array}$ & $\begin{array}{l}\text { Assessment performance in two moments: before } \\
\text { the program and after its completion. } \\
\text { »Cognitive Function: Cognitive Failures } \\
\text { Questionnaire (CFQ) } \\
\text { »Executive functions: The Dyexecutive } \\
\text { Questionnaire (DEX) } \\
\text { »Memory: The Everyday Memory Questionnaire } \\
\text { (EMQ) } \\
\text { »Psychological functioning and well-being: The } \\
\text { Schwartz Outcomes Scale-10 } \\
\text { »Quality of life: Subjective Quality of Life } \\
\text { Questionnaire (SQUALA) } \\
\text { »Depression: Beck Depression inventory-II }\end{array}$ & $\begin{array}{l}\text { Assessment performance in two moments: } \\
\text { before the program and after its completion. } \\
\text { „Primary Outcome (verbal memory): Rey } \\
\text { Auditory Verbal Learning Test (RAVLT) } \\
\text { - Secondary Outcome: Rapid Visual Information } \\
\text { Processing (RVP), Trail Making Test - Part B } \\
\text { (TMT-B) and Functional Assessment Short Test } \\
\text { (FAST) } \\
\text { "Tertiary Outcomes: Repeatable Battery for } \\
\text { the Assessment of Neuropsychological Status } \\
\text { (RBANS), Cognitive Failures Questionnaire (CFQ), } \\
\text { WHO Quality of Life BREF (WHOQOL-Bref), } \\
\text { Cohen's Perceived Stress Scale (PSS), European } \\
\text { Quality of Life, Beck Depression Inventory (BDI) } \\
\text { and Work and Social Adjustment Scale (WSAS). }\end{array}$ & $\begin{array}{l}\text { Assessment performance } \\
\text { in two moments: before } \\
\text { the program and after } \\
\text { its end. } \\
\text { "Cognitive Function: Brief } \\
\text { Assessment of Cognition } \\
\text { in Schizophrenia (BACS) } \\
\text { "Social functioning: Life } \\
\text { Assessment Scale for } \\
\text { Mentally III (LAS III) }\end{array}$ \\
\hline $\begin{array}{l}\text { Intervention } \\
\text { (CS } \\
\text { technique } \\
\text { used and } \\
\text { training } \\
\text { frequency) }\end{array}$ & $\begin{array}{l}\text { The use of the CogniFit software could be } \\
\text { adjusted to customize the training to each } \\
\text { person. Each person performed cognitive training } \\
\text { exercises ( } 15 \text { people) or only received standard } \\
\text { care ( } 16 \text { people) in their own home. The program } \\
\text { comprises } 3 \text { sessions per week, sessions of } 20 \text { to } \\
30 \text { minutes duration, for } 8 \text { weeks. }\end{array}$ & $\begin{array}{l}\text { Group sessions, once a week, sessions lasting } \\
2 \text { hours for } 12 \text { weeks (short-term group-based } \\
\text { cognitive remediation). } \\
\text { Four weeks after the end of the program, a } \\
\text { booster session was held. }\end{array}$ & $\begin{array}{l}\text { Intervention takes place } \\
\text { through the CogPack } \\
\text { software and run twice } \\
\text { a week for } 12 \text { weeks. } \\
29 \text { people performed } \\
\text { cognitive remediation } \\
\text { program, and the other } \\
31 \text { people performed } \\
\text { Treatment Usual (TAU). }\end{array}$ \\
\hline $\begin{array}{l}\text { Nurse as } \\
\text { intervener }\end{array}$ & Not defined. & Not defined. & Not defined. \\
\hline $\begin{array}{l}\text { Caregiver as } \\
\text { intervener }\end{array}$ & $\begin{array}{l}\text { Intervenes in the filling of the DEX questionnaire } \\
\text { in order to assess executive functions of } \\
\text { participants and their relatives. }\end{array}$ & No. & No. \\
\hline Results & $\begin{array}{l}\text { The cognitive training group showed significant } \\
\text { improvements compared to the control group, } \\
\text { depression (lower levels of depression), cognitive } \\
\text { functioning, executive functions, attention and } \\
\text { working memory. } \\
\text { Caregivers/family members noticed } \\
\text { improvements in their family members. }\end{array}$ & $\begin{array}{l}\text { Primary Outcomes: There were no } \\
\text { improvements in verbal memory. } \\
\text { Secondary Outcomes: There were no } \\
\text { improvements in psychosocial functioning or } \\
\text { sustained attention and executive functions } \\
\text { compared to the control group. } \\
\text { Tertiary Outcomes: There have been long-term } \\
\text { improvements in mental acuity, verbal fluency, } \\
\text { and quality of life - a psychological component. } \\
\text { It is unlikely that an increase in the sample } \\
\text { would change the results presented at the } \\
\text { verbal memory level. }\end{array}$ & $\begin{array}{l}\text { The group that } \\
\text { performed cognitive } \\
\text { remediation program } \\
\text { presented better } \\
\text { results than the control } \\
\text { group, namely in terms } \\
\text { of processing speed, } \\
\text { attention, verbal fluency } \\
\text { and executive functions, } \\
\text { as well as improvements } \\
\text { in interpersonal } \\
\text { relationships and work } \\
\text { skills (work skills). }\end{array}$ \\
\hline $\begin{array}{l}\text { Limitations } \\
\text { reported in } \\
\text { the article }\end{array}$ & $\begin{array}{l}\text { - The control group did not take active care } \\
\text { (suggest that an upcoming study also include for } \\
\text { the control group exercises in the computer that } \\
\text { do not directly stimulate cognitive functioning); } \\
\text { - Humor was not assessed in a quantitative and } \\
\text { objective way; } \\
\text { - Limited information to compare the data } \\
\text { collected in this study. }\end{array}$ & $\begin{array}{l}\text { - Small sample; } \\
\text { - Inclusion of people in total remission together } \\
\text { with people in partial remission of their disease. }\end{array}$ & $\begin{array}{l}\text { (not available per article } \\
\text { not fully visible to the } \\
\text { public) }\end{array}$ \\
\hline
\end{tabular}


Among the articles analyzed, there is an article that addresses Cognitive Rehabilitation (article A). Four address Cognitive Remediation (articles B, C, E and F) and one in which they denominate CS as Cognitive Training (article D). However, they all address, using the term or referring in an indirect way, CS interventions as a component that links all cognitive interventions performed in the studies analyzed. It can be concluded that CS, functioning as validation, is, in fact, present in all strategies of cognitive interventions performed. Adding to this conclusion, it is observed that the most used term is Cognitive Remediation, as referred by McGurk and collaborators (2007) ${ }^{(18)}$.

Four of the six articles are on studies of people with schizophrenia (articles A, B, C and F), an article reflects the work with people with unipolar and bipolar disease (article D) and an article with people with bipolar disorder (article E). In fact, a large part of the studies initially analyzed for this review had as a sample people with schizophrenia (of the 25 studies, 17 involving people with schizophrenia or schizoaffective disorder), with less expression of studies on bipolar disorder $(n=3)$. Finally, depression (in addition to the study included in this RIL on unipolar disease, only one study was found on depression after stroke and another on postpartum depression). Going back to the six articles analyzed, the intervention directed to each sample group does not show great differences in its construction and performance: (a) for groups of people with one of the three pathologies mentioned above, computer software was used, (b) duration of each program does not appear to differ much (with an average of 20 to 24 hours) and (c) no specific indications are given to meet certain characteristics of persons with these pathologies.

In a cross-sectional way, and in support of the literature on the theme ${ }^{(19-21)}, C E$ techniques, according to the articles consulted, improved: attention (articles A, D and F), working memory (articles $A, B, C$ and $D$ ), retrospective and prospective memory (article $A$ ), psychomotor speed (article B), speed of processing of complex information (articles B and F), planning ability (article B), verbal learning (article C), problem-solving ability (Article C), executive functions [not specified] (Articles D and F ), and verbal fluency (articles $\mathrm{E}$ and $\mathrm{F}$ ). However, article B reported no improvements in verbal fluency (contradicting articles $\mathrm{E}$ and $\mathrm{F}$ ), and article $\mathrm{E}$ saw no improvement in executive functions (contrary to the comments in articles D and F).

Relating intervention differences analysis directed to each sample group, with the improved cognitive abilities in each study, it was concluded that it is not clear if there are differences in intervention effectiveness in people with different mental illnesses. Gain in terms of memory, attention and executive functions are cross-sectional to all groups of people included in the studies, and there are no evident differences that allow to differentiate CS techniques effectiveness in people with certain pathology.

Of the 6 studies analyzed, only one article (article E) did not resort to the use of computers, tablets or computer software to carry out its intervention. These computer supports were used to assess CS effectiveness in supervised environment (articles A, B and F) and at home (article D). In this case, there is a tendency to use these tools, as Santos $(2015)^{(20)}$ observed during the elaboration of his CS program. One of the studies (article C) sought to determine if there was a difference in cognitive gains when a supervised computer was used compared to using a tablet at home, and concluded that the devices did not influence intervention effectiveness (taking as conclusions that are the young people who prefer, mostly, this type of computer support and that the use of portable devices is as viable as using fixed appliances).

The sample size of each study is also an important data to be analyzed. Ranging between 15 and 79 people, all the samples were small and/or chosen for convenience, contributing this factor to the difficulty in transposing the obtained knowledge, as a confirmed and universal data for clinical practice ${ }^{(20)}$.

The structuring of a CS program has been much discussed in recent research, and there is still no consensus on how it should be structured $^{(20)}$. The six studies analyzed are no exception - among the interventions performed, the number of sessions and duration time varied between 12 hours and 40 total hours of activities, for 8 to 12 weeks, as shown in Table 1.

Table 1 - Structure of Cognitive Stimulation programs in total hours and weeks, 2018

\begin{tabular}{ccc}
\hline Articles & Total number of hours & Total number of weeks \\
\hline A & 20 & 10 \\
C & 40 & 8 \\
D & 12 & 8 \\
E & 24 & 12 \\
F & 24 & 12 \\
\hline
\end{tabular}

Note: article $B$ does not present the detailed program of the sessions, referring to the article by Bowie CR, McGurk SR, Mausbach B, Patterson TL, Harvey PD, called "Combined cognitive remediation and functional skills training for schizophrenia: effects on cognition, and real-world behavior". Am J Psychiatry 2012; 169:710-18.

Program effectiveness is obtained through assessment tools application ${ }^{(22)}$, such as scales or inventories, a fact observed in all studies analyzed, as shown in Chart 2.

Of the 20 scales used by the 6 studies, only the Positive and Negative Syndrome Scale (PANSS), Brief Assessment of Cognition in Schizophrenia (BACS), Cognitive Failures Questionnaire (CFQ) and Beck Depression Inventory (BDI) were used at least in two studies as a means of assessing their intervention effectiveness. Heterogeneity in scale application hinders a more accurate and rigorous critical analysis, since different scales assess different aspects, reason why assessment and comparison of results of different studies is compromised.

Similarly, the time of assessment tool application was slightly different between each study: all of them used pre- and posttest scales (articles A, C, D, E and F - as the study of article B performed the post-test only one week after the conclusion of the program), with only one using the follow-up modality (in two different moments) to guarantee the long-term gains (article A), as can be seen in Chart 3.

These results are not in line with what Santos $(2015)^{(20)}$ tells us, which suggests some wisdom when looking at the results obtained by a study without follow-up. This absence can lead to a great heterogeneity of results, and this constitutes a limitation, as defended by the authors of articles B and C.

One of the main objectives of this integrative review was to understand the role of the nurse and if he is an active member in the realization and operationalization of the programs. In the studies of articles $A$ and $B$, the program was led by psychologists. 
Article $C$ states that the intervention of professionals was minimal (but did not mention which professional class) and articles D, E and $\mathrm{F}$ did not state which professionals were responsible for the intervention. From these results, one can assess that the role of the nurse is quite scarce in relation to CS studies, adding that this subject is apparently being developed more by psychiatrists and psychologists than by nurses.

Chart 2 - Assessment of tools used in each study, 2018

\begin{tabular}{|c|c|c|c|c|c|c|c|}
\hline & Articles & A & B & C & D & $E$ & $\mathrm{~F}$ \\
\hline \multirow{20}{*}{$\frac{\tilde{d}}{\tilde{U}}$} & PANSS & $X$ & $x$ & $x$ & & & \\
\hline & CPTIP & $X$ & & & & & \\
\hline & WAIS & $X$ & & & & & \\
\hline & PRMQ & $X$ & & & & & \\
\hline & BACS & & $x$ & & & & $x$ \\
\hline & SLOF & & $x$ & & & & \\
\hline & MCCB & & & $x$ & & & \\
\hline & QLS & & & $x$ & & & \\
\hline & SFS & & & $x$ & & & \\
\hline & CFQ & & & & $x$ & $x$ & \\
\hline & DEX & & & & $x$ & & \\
\hline & EMQ & & & & $x$ & & \\
\hline & BDI & & & & $x$ & $x$ & \\
\hline & RAVLT & & & & & $x$ & \\
\hline & RVP & & & & & $x$ & \\
\hline & RBANS & & & & & $x$ & \\
\hline & WHOQOL & & & & & $x$ & \\
\hline & PSS & & & & & $x$ & \\
\hline & WSAS & & & & & $x$ & \\
\hline & LAS III & & & & & & $x$ \\
\hline
\end{tabular}

Note: BACS - Brief Assessment of Cognition in Schizophrenia; BDI - Beck Depression inventory; CFQ - Cognitive Failures Questionnaire; CPTIP - Continuous Performance Test Identical Pair Version; DEX - The Dyexecutive Questionnaire; EMQ - The Everyday Memory Questionnaire; LAS III - Life Assessment Scale for Mentally III; MCCB - MATRICS Consensus Cognitive Battery; PANSS - Positive and Negative Syndrome Scale; PRMQ - Prospective and Retrospective Memory Questionnaire; PSS - Cohen's Perceived Stress Scale; QLS - Quality of Life Scale; RAVLT - Rey Auditory Verbal Learning Test; RBANS - Repeatable Battery for the Assessment of Neuropsychological Status; RVP - Rapid Visual Information Processing; SFS - Social Functioning Scale; SLOF-Specific Levels of Functioning; WAIS - Revised Wechsler Adult Intelligence Scale; WSAS - Work and Social Adjustment Scale; WHOQOL-Bref - WHO Quality of life BREF.

Chart 3 - Time of assessment tool application, 2018

\begin{tabular}{|l|l|l|l|l|l|l|}
\hline Assessment moment/Article & A & B & C & D & E & F \\
\hline Before the program and after the end & $\mathrm{x}$ & & $\mathrm{x}$ & $\mathrm{x}$ & $\mathrm{x}$ & $\mathrm{x}$ \\
\hline One month after & $\mathrm{x}$ & & & & & \\
\hline Three months after & $\mathrm{x}$ & & & & & \\
\hline Before the program and 1 week after the end & & $\mathrm{x}$ & & & & \\
\hline
\end{tabular}

Finally, there was the objective of perceiving the effect of the results on informal/family caregivers of this stimulation of cognition in people with schizophrenia or affective disease. Firstly, it was noticed that little intervention happened at home: Articles $C$ and $D$ indicate that users would hold sessions with the laptop/tablet, but there is no reference to an active presence of professionals in people's home. Of the six studies, only one (article D) resorted to a (small) informal caregiver's help by asking the Dyexecutive Questionnaire to fill in (or improve) (d) the executive functions of their relative. Nothing was asked for these caregivers and none of the articles analyzed CS effects on caregivers. Has the role of these actors been poorly studied and (even) undervalued? This is one of the questions that this review leaves to the scientific community.

\section{Study limitations}

One limitation of this review was the fact that the study has turned to two access platforms to the databases, despite the wide scope.

Regarding the results found, the fact that the research dimensions samples are small and mostly of convenience is limited as a limitation, which limits the degree of evidence. Comparison of results is another limitation, since it is limited and compromised by tool variability to measure intervention effectiveness.

\section{Contributions to Nursing, Health or Public Policies}

This research challenges nursing to mobilize these intervention techniques to meet the health needs of many people with more impaired mental health. The effectiveness shown in gains points to a responsibility for nurses and for health policy in general, the need to intervene with these non-pharmacological techniques to boost personal resources and improve people's mental health. It can, with adequate resources, reduce financial costs (medicines and times of direct care of professionals).

\section{FINAL CONSIDERATIONS}

With the goal of learning about the state of the art in terms of results obtained through CS practice, several answers were obtained, but also many questions.

Answers are in line with the objectives outlined: the results obtained in terms of the stimulation of cognition, in a crosssectional way, are revealed by the improvement of capacities such as attention, working memory, processing speed of complex information, executive functions and verbal fluency; it is unclear whether there are differences in CS interventions effectiveness in people with different mental illnesses. However, further studies should be conducted with people with schizophrenia; heterogeneity in assessment tools application makes it difficult to critically assess the results and, consequently, to translate the knowledge obtained; the nurse's role seems to be little analyzed in studies of this nature, as well as the role and gains of these techniques in family/caregivers.

This review leaves the researchers with the following questions: why are there more CS studies on degenerative diseases 
area compared to affective diseases and schizophrenia apparently developed? What are the limitations that influence the study with people with schizophrenia, bipolar disorder and major depressive disorder? What/how should a CS program be structured? In the case of the sample, is it just the sample size that influences the data, or will it also be its characteristics? How does assessment tools heterogeneity affect the assessment of their results? How can it be standardized? And the follow-up, how long after the program end should be accomplished? How many times? And the time period? What is the role of the nurse in CS? What is the role of informal caregivers? And what is the effect on family members?

These and other questions remain open, assuming only from what is already written and studied, but realizing that there is still much to know about this theme.

\section{REFERENCES}

1. Tonelli H, Liboni F, Cavicchioli D. Programas metacognitivos com enfoque em cognição social na reabilitação da esquizofrenia: uma revisão sistemática. J Bras Psiquiatr. 2013;62(1):51-61. doi: 10.1590/S0047-20852013000100008

2. Nuechterlein KH, Ventura J, Subotnik KL, Bartzokis G. The early longitudinal course of cognitive deficits in schizophrenia. J Clin Psychiatry. 2014;75(Suppl 2):25-9. doi: 10.4088/JCP.13065.su1.06

3. Strawbridge R, Fish J, Halari R, Hodsoll J, Reeder C, Macritchie K, et al. The Cognitive Remediation in Bipolar (CRiB) pilot study: study protocol for a randomised controlled trial. Trials. 2016; 17:371. doi: 10.1186/s13063-016-1472-4

4. Matos A, Mourão I, Coelho E. Interação entre a idade, escolaridade, tempo de institucionalização e exercício físico na função cognitiva e depressão em idosos. Motricidade. 2016;12(2):38-47. doi: 10.6063/motricidade.6805

5. Costa ARD, Sequeira C. Efetividade de um programa de estimulação cognitiva em idosos com défice cognitivo ligeiro [Internet]. Rev Port Enferm Saúde Mental. 2013 [cited 2018 Mar 09];9:14-20. Available from: http://www.scielo.mec.pt/scielo.php?script=sci_arttext\&pid $=$ S1647-21602013000100003

6. Vieira J. Reabilitação Cognitiva na Esquizofrenia [Internet]. PsiLogos. 2013 [cited 2018 Mar 09];11(2):22-42. Available from: http://www. psilogos.com/Revista/Vol11N2/Indice15_ficheiros/Reabilitacao\%20cognitiva.pdf

7. Regulamento n. ${ }^{129 / 2011}$ (PT). Diário da República n. ${ }^{\circ}$ 35/2011, Série Il, de 18 de fevereiro de 2011. Define o perfil das competências específicas do enfermeiro especialista em Enfermagem de Saúde Mental [Internet] [cited 2018 Mar 09]. Available from: https://dre.pt/web/ guest/home/-/dre/3477018/details/maximized?jp=true

8. Marques AJ, Queirós C, Rocha NB. Metodologias de reabilitação cognitiva num programa de desenvolvimento pessoal de indivíduos com doença mental e desempregados de longa duração. Psicol Saúde Doenças [Internet]. 2006 [cited 2018 Mar 09];7(1):109-16. Available from: http://www.scielo.mec.pt/scielo.php?script=sci_arttext\&pid=S1645-00862006000100009

9. Sousa L, Sequeira C. Concepção de um programa de intervenção na memória para idosos com défice cognitivo ligeiro. Rev Port Enferm Saúde Mental [Internet]. 2012 [cited 2018 Mar 09];8:7-15. Available from: http://www.scielo.mec.pt/scielo.php?script=sci_arttext\&pid $=$ S1647-21602012000200002

10. Vita A, De Peri L, Barlati S, Cacciani P, Deste G, Poli R, et al. Effectiveness of different modalities of cognitive remediation on symptomatological, neuropsychological, and functional outcome domains in schizophrenia: A prospective study in a real-world setting. Schizophr Res. 2011;133(1-3):223-31. doi: 10.1016/j.schres.2011.08.010

11. Mohammadi M, Keshavarzi Z, Talepasand S. The Effectiveness of Computerized Cognitive Rehabilitation Training Program in Improving Cognitive Abilities of Schizophrenia Clients. Iran J Psychiatry [Internet]. 2014 [cited 2018 Mar 09];9(4):209-15. Available from: https://www. ncbi.nlm.nih.gov/pmc/articles/PMC4361823/

12. Bowie C, Grossman M, Gupta M, Oyewumi LK, Harney P. Cognitive remediation in schizophrenia: efficacy and effectiveness in patients with early versus long-term course of illness. Early Interv Psychiatry. 2014;8(1):32-8. doi: 10.1111/eip.12029

13. Biagianti B, Fisher M, Howard L, Rowlands A, Vinogradov S, Woolley J. Feasibility and preliminar efficacy of remotely delivering cognitive training to people with schizophrenia using tablets. Schizophr Res Cogn. 2017;10:7-14. doi: 10.1016/j.scog.2017.07.003

14. Preiss $M$, Shatil E, Cermákova R, Cimermanová D, Ram I. Personalized cognitive training in unipolar and bipolar disorder: a study of cognitive functioning. Front Hum Neurosci. 2013;7:108. doi: 10.3389/fnhum.2013.00108

15. Demant K, Vinberg M, Kessing L, Miskowiak K. Effects of short-term cognitive remediation on cognitive dysfunction in partially or fully remitted individuals with bipolar disorder: results of a randomised controlled trial. PLoS One. 2015;10(6):e0127955. doi: 10.1371/journal. pone. 0127955

16. Iwata K, Matsuda Y, Sato S, Furukawa S, Watanabe Y, Hatsuse N, et al. Efficacy of cognitive rehabilitation using computer software with individuals living with schizophrenia: A randomized controlled trial in Japan. Psychiatr Rehabil J. 2017;40(1):4-11. doi: 10.1037/prj0000232

17. Guerreiro M. Avaliação Neuropsicológica das Demências Degenerativas. In: Castro-Caldas A, Mendonça A, coordenadores. A Doença de Alzheimer e outras demências em Portugal. Lisboa: Lidel; 2005. p. 83-109.

18. McGurk S, Twamley E, Sitzer D, McHugo G, Mueser K. A Meta-analysis of cognitive remediation in schizophrenia. Am J Psychiatry. 2007;164(12):1791-802. doi: 10.1176/appi.ajp.2007.07060906

19. Ahmed AO, Hunter KM, Goodrum NM, Batten NJ, Birgenheir D, Hardison E, et al. A randomized study of cognitive remediation for forensic 
and mental health patients with schizophrenia. J Psychiatr Res. 2015;68:8-18. doi: 10.1016/j.jpsychires.2015.05.013

20. Santos MMTLR. PROECO - Um Programa de Estimulação Cognitiva para um Envelhecimento Saudável [Tese] [Internet]. Porto: Universidade Fernando Pessoa; 2015 [cited 2018 Mar 09]. Available from: https://bdigital.ufp.pt/bitstream/10284/5199/1/Tese\%20Maria\%20Santos.pdf

21. Tan S, Liu D. A review of the Chinese literature on cognitive remediation in psychosis. Asian J Psychiatr. 2016;22:129-34. doi: 10.1016/j. ajp.2016.06.012

22. Costa AR. Efetividade de um programa de Estimulação Cognitiva em idosos com défice cognitivo ligeiro [Dissertação] [Internet]. Porto: Escola Superior de Enfermagem do Porto; 2012. Available from: https://comum.rcaap.pt/handle/10400.26/9319 